\title{
RISKS OF LAND MARKET FUNCTIONING AND THEIR PREVENTIVE MEASURES
}

\author{
Olena Plutalova \\ Postgraduate Student at the Department of Humanities \\ of the Donetsk State University of Management, Ukraine \\ e-mail: 4994329@gmail.com, orcid.org/0000-0001-8888-3781
}

\section{Summary}

In the article, the author examines the current state of completion of land reform in order to clarify the biggest problems related to the opening and further functioning of the free land market in Ukraine, as well as the search for effective preventive measures against possible risks. Emphasizing the value of land as a resource for the full economic and social development of the country, the author emphasizes the importance of efficient and rational use. In this regard, the most important risks of market relations have been highlighted, such as insufficient solvency of future farmers, possible monopolization of agriculture by agricultural holdings, difficult conditions for lending to agricultural needs, lack of effective state regulation of land sales, etc. As a result of the research, the Article highlights and substantiates ways to minimize risks.

These include mandatory state financial support for farmers, including newly incorporated farms, the need to create a credit infrastructure focused on servicing the agricultural economy, accelerating the process of determining the regulatory monetary valuation of each land that will become a commodity in the land market, and the need to improve mechanisms of state regulation of land relations. The Article also analyzes the current regulations governing relations in this area, as well as the positive experience of foreign countries.

Keywords: state regulation, land relations, farms, land sale, state support, crediting.

DOI: https://doi.org/10.23856/4528

\section{Introduction}

The launch of the land market in Ukraine in July this year raises the issue of effective public administration in the field of land relations, as land in our country with an agro-industrial economy is a powerful financial asset.

Thus, the rational use of land and income from it affect the economic growth of the country as a whole and each individual farm. Proper land administration is a major factor in employment, particularly in the country's agricultural regions, improving welfare, and combating labor emigration as a result of establishing political stability in the country.

In this regard, the study of possible risks, problems of the land market functioning in order to prevent or minimize them by taking balanced steps along the lines of the ongoing land reform is becoming extremely important.

Researchers such as R. Bezpalko, I. Bystriakov, Yu. Bilyk, D. Hnatkovych, O. Hutorov, A. Danylenko, B. Danylyshyn, O. Datsii, D. Dobriak, S. Dorohuntsov, O. Dorosh, O. Yevhrafov, P. Kazmir, M. Koretskyi, M. Latynin, M. Stupen, A. Tretiak and others devoted their works to the study of general theoretical issues of land management and land development, as well as to the issues of land relations reform. 
However, so far, the possible risks of the first stage of opening the land market have not been specified and no ways to avoid or minimize them have been proposed (preventive measures).

This was the purpose of the study, the results of which are set out in the Article. For this purpose, the current legal framework, which is the basis of the legal mechanism of state regulation of land relations, the positive experience of foreign countries with developed and stable land markets, statistics of the State Service of Ukraine for Geodesy, Cartography and Cadastre, the work of scientists has been studied and analyzed. In the course of work the general methods of research (analysis and synthesis, induction and deduction, generalization), and also methods of theoretical research (convergence from abstract to concrete) are used.

\section{General characteristics of the current state of land relations}

Market land relations in Ukraine have two components: the market of non-agricultural land, which includes, first of all, land for construction, maintenance of buildings and under buildings, and the market of agricultural land, where land is the basis of production and participates in food creation. According to the State Service of Ukraine for Geodesy, Cartography and Cadastre for the precious 2020, 3151 non-agricultural land plots with a total area of 2076.34 hectares have been sold. The State received 1,540.7 mln UAH from the sale (State Service of Ukraine for Geodesy and Cartography, 2021).

At the same time, agricultural lands are of the greatest value, the efficient use and disposal of which are a factor in the full economic and social development of the country.

Thus, the total land area in Ukraine is $60.4 \mathrm{mln}$ hectares. Therefrom, $70 \%-42.4 \mathrm{mln}$ hectares are agricultural land, of which more than 32 million hectares are cultivated annually. For comparison, in Poland, agricultural production involves half the area $-14 \mathrm{mln}$ ha, in Germany - $12 \mathrm{mln}$ ha, in Romania - 9 mln hectares. The amount of black soil in Ukraine is the largest in the world and is $28 \mathrm{mln}$ hectares (State Service of Ukraine for Geodesy and Cartography, 2021).

That is why proper state regulation of agricultural land is a priority. For almost 30 years, in Ukraine, land relations are being reformed through their gradual transformation into a market one. The last 5 years have been "breakthrough" in the formation of the main components of the land market, namely: the creation of an appropriate legal framework, the process of land formation as an object of purchase and sale through gradual registration of land plots has started, the process of decentralization of land relations and land inventory has started, the mechanism of land electronic auctions has introduced, access to land information was facilitated, including through the introduction of a public cadastral map, etc.

Currently, the State is on the verge of opening the agricultural land market. Thus, in accordance with the Law of Ukraine "On Amendments to Certain Legislative Acts of Ukraine on the Circulation of Agricultural Land" dated 31.03.2020 No. 552-IX since July 1, 2021, citizens of Ukraine have the right to own agricultural land up to 100 hectares, and since January 1 , 2024, such an opportunity will be given to legal entities owned by Ukrainians. They will be able to buy up to 10,000 hectares of land (Verkhovna Rada of Ukraine, Law No. 552-IX, 2020).

At the same time, there are categorically opposite positions in the society regarding the sale of these lands due to the presence of certain risks and problems related to the functioning of the land market. 


\section{State support of farming as a preventive measure for the monopolization of the land market}

One of these is the risk of concentrating large areas of agricultural lands owned by companies-landowners. The so-called "latifundists", who will use the labor of peasants for meager wages. This will have a negative impact on the social situation of the latter and may provoke the outflow of able-bodied citizens from agricultural regions of the country to industrial or abroad in search of a better life.

In order to counteract the process of monopolization of agriculture by agricultural holdings, the Law of Ukraine "On Amendments to Certain Legislative Acts of Ukraine on the Circulation of Agricultural Land", as already mentioned, legal entities registered in Ukraine are allowed to buy land only since January 1, 2024 and no more than 10 thousand hectares of land.

Thus, the legislator gives priority right for the election and acquisition of land plots to citizens. At the same time, according to the provisions of this Law, citizens of Ukraine, who have the right of permanent use, the right of lifelong inherited ownership of land plots of state and communal property intended for peasant (farmer) economy, as well as tenants of land plots that have acquired the right to lease land plot by re-issuing the right of permanent use in respect of these land plots until 2010, have the right to purchase such land plots in the property with installments of up to ten years at a price equal to the normative monetary value of such land plots, without holding land auctions. In the case of purchase of land plot with installment payment, ownership passes to the buyer after payment of the first payment (Verkhovna Rada of Ukraine, Law No. 552-IX, 2020).

It should be noted that the purchasing power of citizens due to the unsatisfactory level of income in the agricultural sector, the general economic crisis in the country, exacerbated by the ongoing armed conflict in the east, a pandemic and other factors, is extremely low. In order to provide state support for farming, the draft Law of Ukraine "On Amendments to Certain Legislative Acts of Ukraine Concerning Stimulation of Farms' Activities” No. 4046 dated 03.09.2020 was sent to the Verkhovna Rada of Ukraine, which introduced significant amendments to the Law of Ukraine "On Farming".

According to this draft legislation, farms, including newly incorporated ones in the period of formation (the first three years after its incorporation), are provided with assistance from the state, as well as from local budgets. For this purpose, the Cabinet of Ministers of Ukraine should annually provide funds in the draft State Budget of Ukraine to support farms, and local executive bodies and local governments in draft local budgets.

In addition, additional state support is provided to family farms, in particular for the payment of a single contribution to the obligatory state social insurance.

The farm, the head of which is under the age of 35 (inclusive), is provided with financial assistance at the expense of the state budget in the amount and manner established by the Cabinet of Ministers of Ukraine.

Financial support will also be provided through the Ukrainian State Farm Support Fund, including in cases provided by law on a non-refundable basis and in the form of guarantees, sureties for lending by banks to farms (Verkhovna Rada of Ukraine, draft Law 4046, 2020).

The Cabinet of Ministers of Ukraine in the state budget for 2021 provided 4.7 bln UAH to support the agro-industrial complex, which is 700 million more than in 2020. It is expected that about 9,000 agricultural enterprises will receive assistance.

By its Resolution of 07.02.2018 No. 106 (as amended on 21.04.2021), the Cabinet of Ministers of Ukraine approved the Procedure for using funds provided in the state budget to 
provide financial support for the development of farms, which defines the mechanism for using funds provided in the state budget under the program "Financial support for agricultural producers". Thus, financial assistance is provided in the form of partial reimbursement of costs to farms related to the provision of agricultural advisory services (except for newly incorporated); financial assistance for newly incorporated farms to receive agricultural advisory services; budget subsidy up to UAH 5,000 per unit of arable land (1 hectare) to newly incorporated farms; a special budget subsidy for keeping cows of all areas of productivity to a farm, which owns five cows, identified and registered in accordance with the law (Cabinet of Ministers of Ukraine, Resolution No. 106, 2018).

\section{Lending in the agricultural sector}

Activities in the agricultural sector are not possible without lending. For the stable functioning of the production process, farms need material and financial resources. First of all, it is accumulated own funds. However, if we consider the expansion of the economy through the acquisition of land and the increase, in this regard, the cost of machinery, fuels, seeds, fertilizers or the creation of farms for the first time, the need for credit for the farmer is undeniable.

Therewith, there are also certain risks. In Ukraine, there is no specialized bank for lending, namely, the needs of agriculture, which should take into account the duration of lending for this type of activity, conditions and features of production, including its risks due to high probability of financial instability, insurance costs in agricultural production etc. For example, such an institution in one form or another functions effectively in France, the Netherlands, Hungary, Belgium, Denmark, Germany and other countries (Hudz, 2003).

On the other hand, not all farmers, including newly incorporated ones, have proper experience of cooperation (credit history) with commercial banks, and also have property of sufficient value as collateral to obtain a loan. In addition, commercial banks do not provide long-term loans, which are necessary for the optimal development of farms. They are also not interested in providing so-called "credit vacations" due to force majeure (sharp rise in energy prices, lower prices for agricultural products, lack of income due to crop failure, natural disasters, personal circumstances, etc.), but reserve the right to change the terms of payment of the loan unilaterally. Such a provision will not allow citizens to fully exercise their legal right to purchase land and create an efficient farm.

Certainly, the State takes certain measures to amortize these risks. For 2021, the budget program "Financial support for agricultural producers" in the area of "Financial support for measures in the agro-industrial complex by reducing the cost of loans" provides $1.2 \mathrm{bln} \mathrm{UAH}$.

The total amount of loans that has already been attracted by enterprises -7.9 bln UAH, of which preferential (subject to compensation) - UAH 7.3 bln UAH, including:

- by types of loans:

short-term: $-2,4$ bln UAH $(33,1 \%)$;

medium-term - 2,6 bln UAH (35,2\%);

long-term - 2,3 bln UAH (31,7\%);

- by type of activity of borrowers:

livestock sector - 1,3 bln UAH $(17,6 \%)$;

other sectors $-6,1$ bln UAH $(82,4 \%)$.

The average interest rates of banks, at which the subjects of the agro-industrial complex attracted loans, were $14-16 \%$ per annum. Currently, 24 commercial banks have participated in the provision of compensation for loans (Information and Analytical Portal of AIC, 2021). 
Compensation is provided to borrowers for accrued and paid interest on loans use in the current year in the amount of 1.5 of the discount rate of the National Bank, effective on the date of accrual of interest, but not more than the amounts provided by loan agreements, reduced by 5 percentage points. The amount of compensation provided to borrowers and related persons during the budget year on short-term, medium-term and long-term loans may not exceed UAH $15 \mathrm{mln}$ UAH for borrowers working in the livestock sector, for other borrowers - not more than UAH 5 mln UAH (Cabinet of Ministers of Ukraine, Resolution No. 300, 2015).

As can be seen from the above, the State has already created a certain organizational and administrative mechanism to support farmers. However, with the start of land circulation, it will not be able to operate effectively, including due to the significant burden on the country's budget. Therefore, without rejecting the need for state financial support for cheaper loans, the gradual transition from preferential lending for one-time measures to credit support for the agro-industrial sector as a whole should be considered. This involves the creation of an appropriate agreed system of credit security of economic entities on a competitive basis, taking into account the objective characteristics of the industry. The elements of such a system should be a credit infrastructure focused on servicing the agricultural economy; mechanism of credit relations with commercial banks; non-bank lending mechanism (Demianenko, 2014).

\section{Monetary valuation of land plot}

Another important issue at the first stage of land market opening is the definition of a real and adequate regulatory monetary valuation of land plot. Whereas, in accordance with the requirements of the Law of Ukraine "On Amendments to Certain Legislative Acts of Ukraine on the Circulation of Agricultural Land" the value of agricultural land plot, as the subject of the sale agreement, is equal to its regulatory monetary value. Section X "Transitional Provisions" of the Land Code of Ukraine is supplemented by paragraph 22, according to which until January 1, 2030, the sale price of agricultural land allocated in kind (on the ground) to owners of land shares (units) may not be less than their normative monetary valuation (Verkhovna Rada of Ukraine, Law No. 552-IX, 2020). According to the State Service of Ukraine for Geodesy, Cartography and Cadastre, as of 01.04.2021, the normative monetary assessment has not yet been conducted on 15,906 land plots (State Service of Ukraine for Geodesy, Cartography and Cadastre, 2021).

That is, the State faces the task of developing not only a transparent and clear mechanism for monetary valuation of land plot to avoid both land speculation and prevent the purchase of fertile land at knockdown price, but also to ensure effective control over market turnover. Currently, there is no special institution in Ukraine with state regulation of the agricultural land market, such as the Agency for Land Management and Sales in Germany, the Agency for Agricultural Real Estate in Poland or the Agency for Land Management and Rural Development in France (Suprun, 2019). In our opinion, the experience of these countries in creating such an institution is quite acceptable for Ukraine.

\section{Conclusions}

The present time is characterized by active steps of the State towards the completion of land reform. At the same time, the formation and establishment of the market circulation of agricultural land is characterized by certain challenges to the proper state regulation of the land market, which will start working in the near future. The first stage of the functioning of the land 
market will be characterized by the realization by Ukrainians of the right to own agricultural land. This process involves certain economic, financial and social risks.

First, the purchasing power of Ukrainians during the economic crisis, burdened by a prolonged pandemic, rising energy tariffs, political instability is not sufficient and requires significant state financial support. It should be noted that the State also needs to solve the social and infrastructural issues of villages and settlements in order to prevent the outflow of the working population from the regions where farming should develop. This is of great importance for the formation of the land market, the subjects of which at the first stage are citizens, not large agricultural holdings. The so-called "village-preserving" policy, which promotes family-type farming, will minimize the risks of concentrating large areas of agricultural land owned by companies-landowners.

Second, lending is not an integral part of market land relations. The current procedure for lending to agricultural producers is not sufficiently adapted to market relations and needs significant revision. Apart from the state budget program aimed at reducing the cost of loans, there are no financial and credit mechanisms adapted to the specifics of the agricultural sector, which would provide financial support to farmers in the functioning of the land market. Risks of shortage of credit resources, high interest rates, lack of developed and coordinated lending system, and bureaucracy of loans will interfere with integral land market relations. In this regard, the creation of credit infrastructure focused on servicing the agricultural economy, mechanisms of credit relations with commercial banks, as well as mechanisms of non-bank lending is necessary.

Thirdly, it is extremely important to determine the normative monetary value of each land plot that will become a commodity on the land market. This process has not been completed yet, despite the short period left before the start of land sales. In addition, no institution is endowed with sufficient powers to regulate the agricultural land market. When there is no an institution, the functioning of civilized market relations should not be expected. Therefore, in this regard, it is worth referring to the positive experience of other countries with developed and stable land markets.

The Article outlines only the main "hot" points of the first period of land market opening. However, there are other significant risks that need to be analyzed in order to prevent or minimize them. This is an area for further research.

\section{References}

Hudz, O. Ye. (2003). Zabezpechennia silskohospodarskykh pidpryiemstv kredytnymy resursamy. Economika APK [Providing agricultural enterprises with credit resources. Economics of agro-industrial complex]. No. 1. P. 86-90. [in Ukrainian]

Demianenko, M. Ya. (2014). Kredytnyi factor staloho rozvytku ahrarnoho sectoru Ukrainy. Ekonomica APK [Credit factor of sustainable development of the agricultural sector of Ukraine. Economics of Agro-Industrial Complex]. No. 11. P. 5-14.

Information of the State Service of Ukraine for Geodesy, Cartography and Cadastre. URL: https://land.gov.ua.

Information of the State Service of Ukraine for Geodesy, Cartography and Cadastre. URL: https://land.gov.ua/info/dovidnyk-pokaznykiv-normatyvnoi-hroshovoi-otsinky-zemelnaselenykh-punktiv-stanom-na-01-01-2021 (access date 06.05.2021)

For three months, farmers were charged 86 million UAH of compensation for attracted loans. Information and analytical portal of the AIC of Ukraine. URL: https://agro.me.gov.ua/ua/news/ 
za-tri-misyaci-silgospvirobnikam-narahovano-86-mln-grn-kompensaciyi-za-zalucheni-krediti (access date 06.05.2021).

Law of Ukraine On Amendments to Certain Legislative Acts of Ukraine Concerning the Circulation of Agricultural Lands: Law of Ukraine of 31.03.2020 No. 552-IX. URL: https://rada.gov. ua/news/actual/191679.html (access date 26.04.2021).

The Procedure for using the funds provided in the state budget to provide financial support for the development of farms approved by the Resolution of the Cabinet of Ministers of Ukraine dated 07.02.2018 No. 106 (as amended by the Resolution of the Cabinet of Ministers of Ukraine dated 21.04.2021 No. 384). URL: https://zakon.rada.gov.ua/laws/show/384-2021-\%D0\%BF\#Text (access date 04.05.2021).

The Procedure for using the funds provided in the state budget for financial support of measures in the agro-industrial complex by reducing the cost of loans approved by the Resolution of the Cabinet of Ministers of Ukraine of April 29, 2015, No. 300 (as amended by the Resolution of the Cabinet of Ministers of Ukraine of March 3, 2020 No. 202) URL: https://zakon.rada.gov.ual laws/show/300-2015-\%D0\%BF \#Text (access date 06.05.2021).

On Amendments to Certain Legislative Acts of Ukraine Concerning the Stimulation of Farms' Activities: Draft Law of Ukraine No. 4046 dated 03.09.2020. URL: http://w1.c1.rada.gov.ua/ pls/zweb2/webproc4_1?pf3511=69824 (access date 28.04.2021)

Suprun, O.M. Svitovyi dosvid zaprovadzhennia rynku zemli ta ioho adaptatsiia do ukrainskyi realii. Holos Ukrainy [World experience of land market introduction and its adaptation to Ukrainian realities. Voice of Ukraine from 04.10.2019]. URL: http://www.golos.com.ua/article/322369 (access date 06.05.2021). [in Ukrainian] 